\title{
Integrated Hydrogeological and Hydrogeophysical Exploration for Groundwater in parts of Gidan-Kwano and Gidan-Mangoro, North-central Nigeria
}

\author{
Amadi A.N. ${ }^{1,}{ }^{*}$, Olasehinde P.I. ${ }^{1}$, Jimoh M.O. ${ }^{1}$, Okoye N.O. ${ }^{1}$, Aminu Tukur ${ }^{2}$ \\ ${ }^{1}$ Department of Geology, Federal University of Technology, PMB 65, Minna \\ ${ }^{2}$ Katsina State Rural Water Supply and Sanitation Agency, Nigeria
}

Copyright $(0) 2015$ Horizon Research Publishing All rights reserved.

\begin{abstract}
The movement of Federal University of Technology, Minna to its permanent site, Gidan Kwano Campus has led to the growth and development of Gidan-Kwano and Gidan-Mangoro as well as increase in demand of water for drinking and domestic purposes. Vertical electrical sounding employing the Schlumberger electrode configuration was employed in this study to characterize the subsurface lithology and provide useful information on groundwater potential of the area. The vertical electrical sounding curves obtained from the area revealed three geo-electric layer characteristics of a basement complex terrain and comprises of top-soil layer, weathered/fractured basement and the fresh basement. The study area has been found to have a high potential for groundwater development. Evidence of deep weathering and fracturing (joints and faults) were observed during the geological mapping of the area. The Interpreted principal joint direction coincides with the direction of stream flow suggesting a structurally controlled drainage system in the area. It implies that the NNE-SSW fracturing system in the area controls the basement weathering as well as groundwater flow system in the area. These zones of deep weathering and basement fractures are high groundwater potential area.
\end{abstract}

Keywords Geological Mapping, Groundwater Exploration, Vertical Electrical Sounding, Gidan-kwano, Gidan-Mangoro, North-central Nigeria

\section{Introduction}

Water is life and its availability governs civilization and industrialization sites. Efforts should continue to be directed at providing potable water till every household can access clean, pure and safe water. Part of these efforts has been in exploration and drilling boreholes to exploit groundwater for private and community water supply. The success of this effort hinges largely on successful groundwater prospection. Many geophysical methods can be employed for groundwater prospection. The electrical resistivity method is employed in this work because it is efficient and cost-effective (Olasehinde and Amadi, 2009).

In electrical resistivity method, artificially generated electric current are introduced into the ground and the resulting potential difference are measured at the surface. It is based on the measurement of the electrical resistivity of the ground which is dependent primarily on the porosity, fracturing, degree of saturation and the salinity of the pore water (Etu-Efeotor and Akpokodje, 1990). Electrical resistivity method has been used successfully by many geoscientists to evaluate groundwater potential in different parts of the Basement Complex rocks (Offodile, 1983; Olorunfemi and Fasuyi, 1993). Although the electrical resistivity method will never replace test drilling for quantifying aquifer yield, it has reduced the cost and incidents of drilling abortive boreholes. The basement complex terrain has many challenges as regards to groundwater potential evaluation (Olasehinde and Amadi, 2009) and it explains why well yield in basement complex is lower than well yield in sedimentary terrain (Adeleye, 1976; Ajibade and Woakes, 1976; Shekwolo, 1993; Grant, 1978; Olarewaju et al., 1996).

The present study is targeted at evaluating the groundwater potential of parts of Gidan-Kwano and Gidan-Mangoro through combined hydrogeological and hydrogeophysical investigation, thereby finding lasting solution to the acute water scarcity encountered by the people in the area. The elucidation of geo-structural signatures and groundwater potentials analysis are more effective by the use of multi-sensor approach than any singular method.

\section{Materials and Method}

\section{Study Area Description}


Both Gidan-Kwano and Gidan-Mangoro are situated along Minna-Bida road, between latitude $9^{0} 24^{\prime} \mathrm{N}$ to $9^{0} 58^{\prime} \mathrm{N}$ of the Equator and longitude $6^{0} 24^{\prime} \mathrm{E}$ to $6^{0} 48^{\prime} \mathrm{E}$ of Greenwich Meridian. The area falls within the guinea savannah vegetation comprising various species of shrubs and high forest plants along the streams and depressions. The area also consists of short grasses of heights ranged between $2 \mathrm{~m}$ to $5 \mathrm{~m}$ with some trees of about $15 \mathrm{~m}$ high. There are two seasons in the area are the rainy and dry seasons. The area is drained by River Dagga and its tributaries (Rivers Weminafia and Kwakodna) flowing in NNE-SSW direction in accordance with one of the fracture patterns in the area. The area falls within the Guinea savanna vegetation comprising grasses, shrubs and trees with greater concentration of the trees found along river channels.

\section{Geology of the Area}

An accurate interpretation of resistivity data of an area may not be obtained without a good knowledge of the local geology, hence a detailed geological mapping of the area was carried out. About half of the land mass of Niger State is underlain by the Basement Complex rocks while the remaining half is occupied by the Cretaceous Sedimentary rocks of the Bida Basin. It lies within the north-central portion of the Nigerian Basement complex rock which is characterized by three lithofacies: the migmatite-gneiss complex, the low grade schist belt and the older granites (Olarewaju, et al., 1996; Olasehinde, 1999). The geological mapping revealed that the area is underlain by granites with different degree of weathering and fracturing.

\section{Fieldwork}

Regional geological map of the area published by Geological Survey of Nigeria was studied to gain knowledge on its regional geology. This was followed with local field reconnaissance survey to verify the lithofacies on regional geology map. Joint directions were measured in the field and rosette diagram made to ascertain the principal joint axes.

An ABEM Terrameter (SAS) 300B with a liquid crystal digital read-out and automatic signal averaging micro-processor was used for data acquisition. A total of 30 vertical electrical soundings were carried out across the area, using the schlumberger symmetrical electrode array configuration. The sounding data were interpreted using Zohdy and Winresist interpretation softwares. The interpretations were controlled using available borehole stratalog data in the area.

\section{Results and Discussion}

The field vertical electrical sounding data obtained was analyzed and representative winresist modelled subsurface resistivity variation curves typical of the area are shown in Figures 1 . The results revealed that low resistivity values (high conductivity values) coincide with areas of deep weathering while high resistivity (low conductivity) indicates shallow basement depth. Areas with H-type curves were recommended for exploitation. It is the apparent resistivity curve for a three-layer subsurface structure in which the intermediate layer has the minimum resistivity (Figure 1). The middle layer is typically the groundwater saturated weathered/fractures zone sandwiched between the highly resistive top soil and the highly resistive dry, unfractured basement. It is common apparent resistivity curve type in the basement terrains in which the basement rocks are partly fractured/weathered. Thus the intermediate layer is of hydrogeological importance. The length and extent of flatness of the minimum apparent resistivity portion of the curve is directly proportional to the thickness of the water saturated intermediate layer.
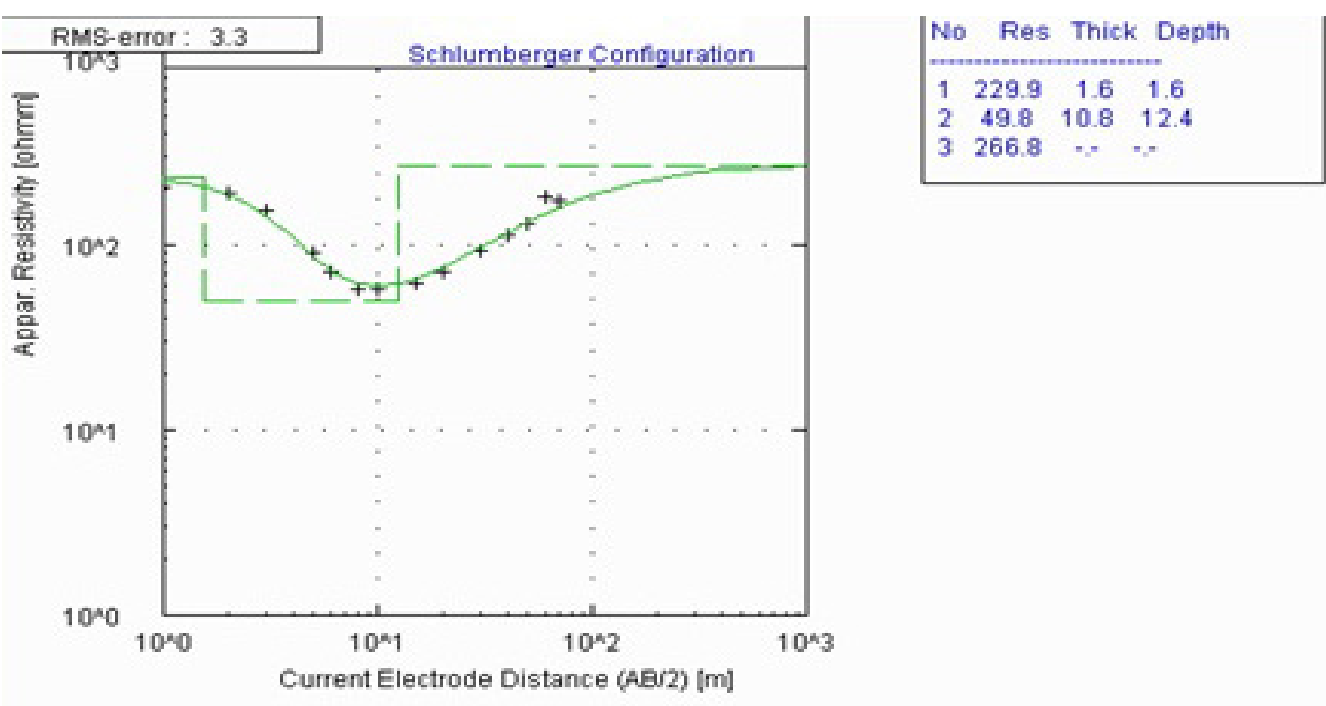

Figure 1. HA-curve in the area 


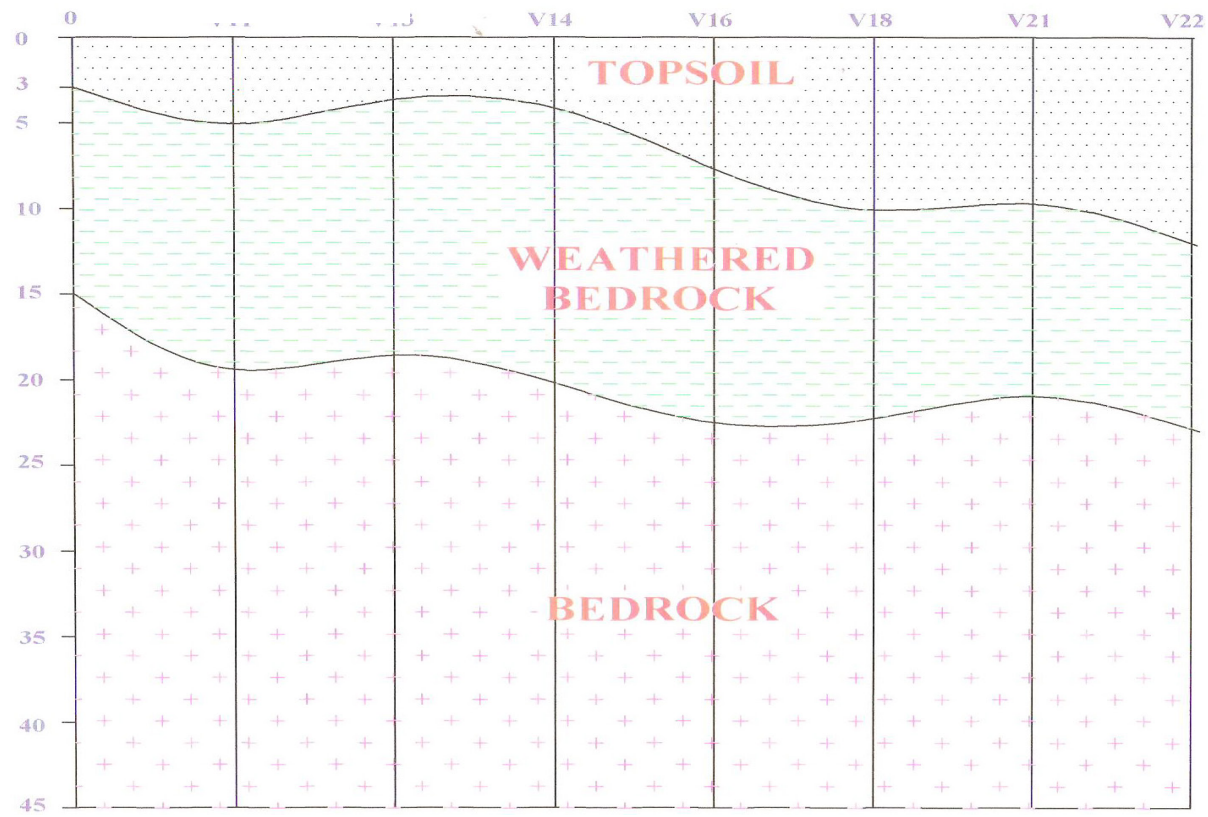

Figure 2. The Geo-electric Section (Vertical scale in metres)

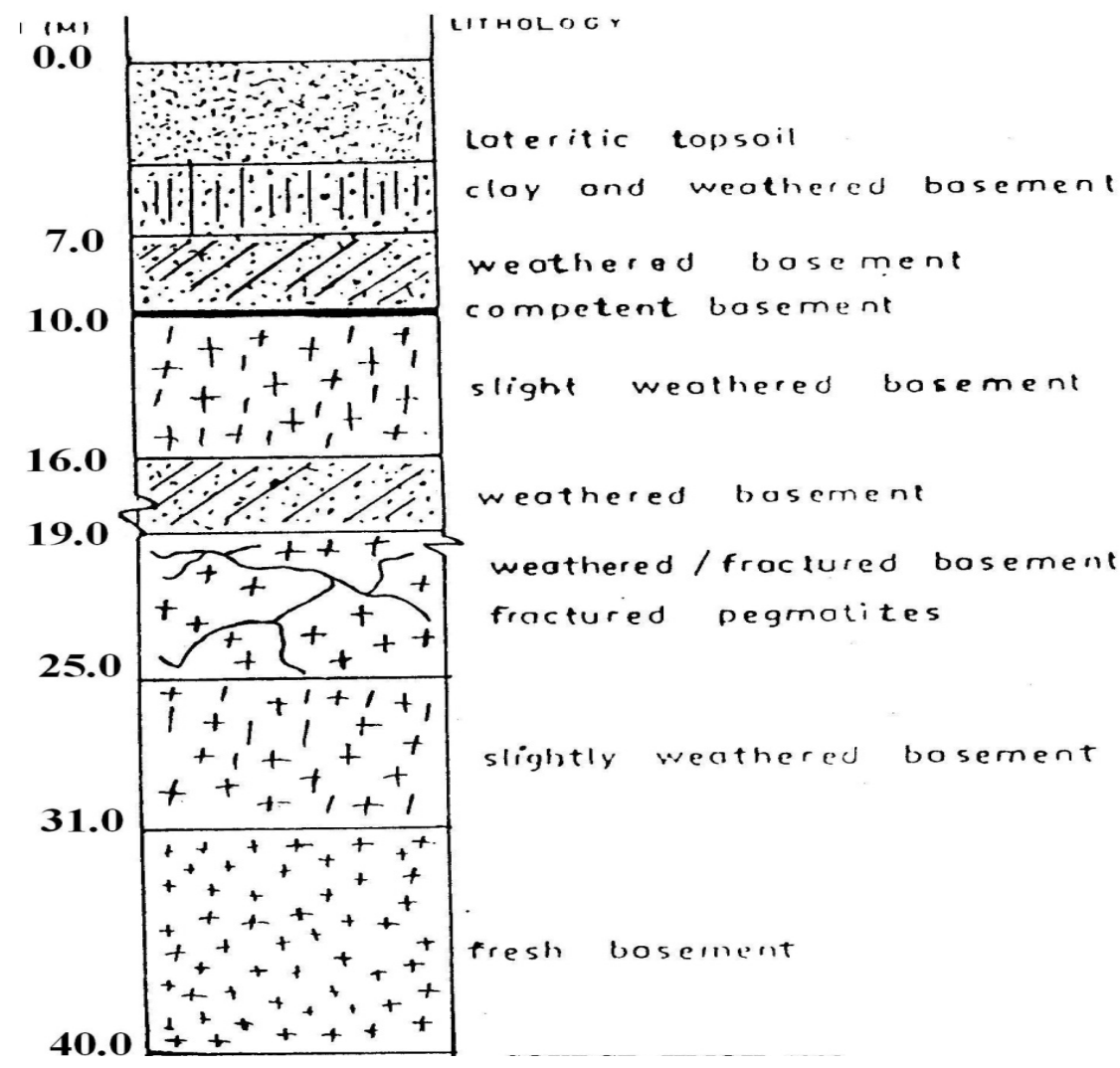

Figure 3. Borehole strata-log (Jimoh, 1998)

The vertical electrical sounding (VES) curves obtained were collaborated with the associated geo-electric layers and the signatures obtained were similar (Figure 2). Furthermore, the obtained geo-electric sections were correlated with available borehole strata-logs (Figure 3) from the area and the same three layer signature was obtained. This consistency of a three layer model from the VES curve, geo-electric section and borehole strata-log (Figures 1-3) is an indication that the study area has a good groundwater potential.

Figure 4 shows the pseudo vertical resistivity section along a profile and it also indicates deep weathering and basement fracturing in a NNE-SSW trending zone. This finding is in conformity with the rosette diagram in (Figure 5) and the fracture map (Figure 6). 


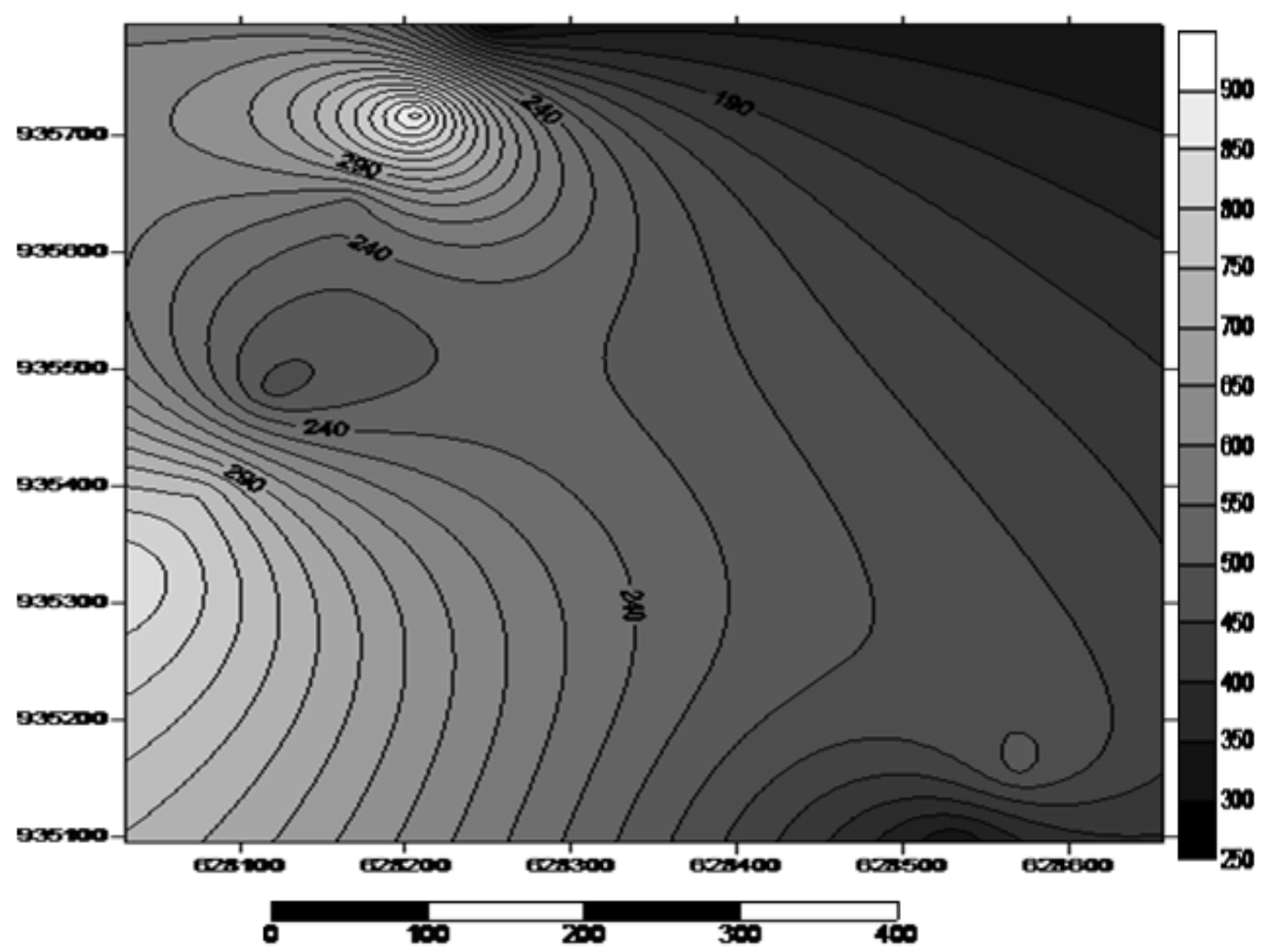

Figure 4. pseudo vertical resistivity section along a profile

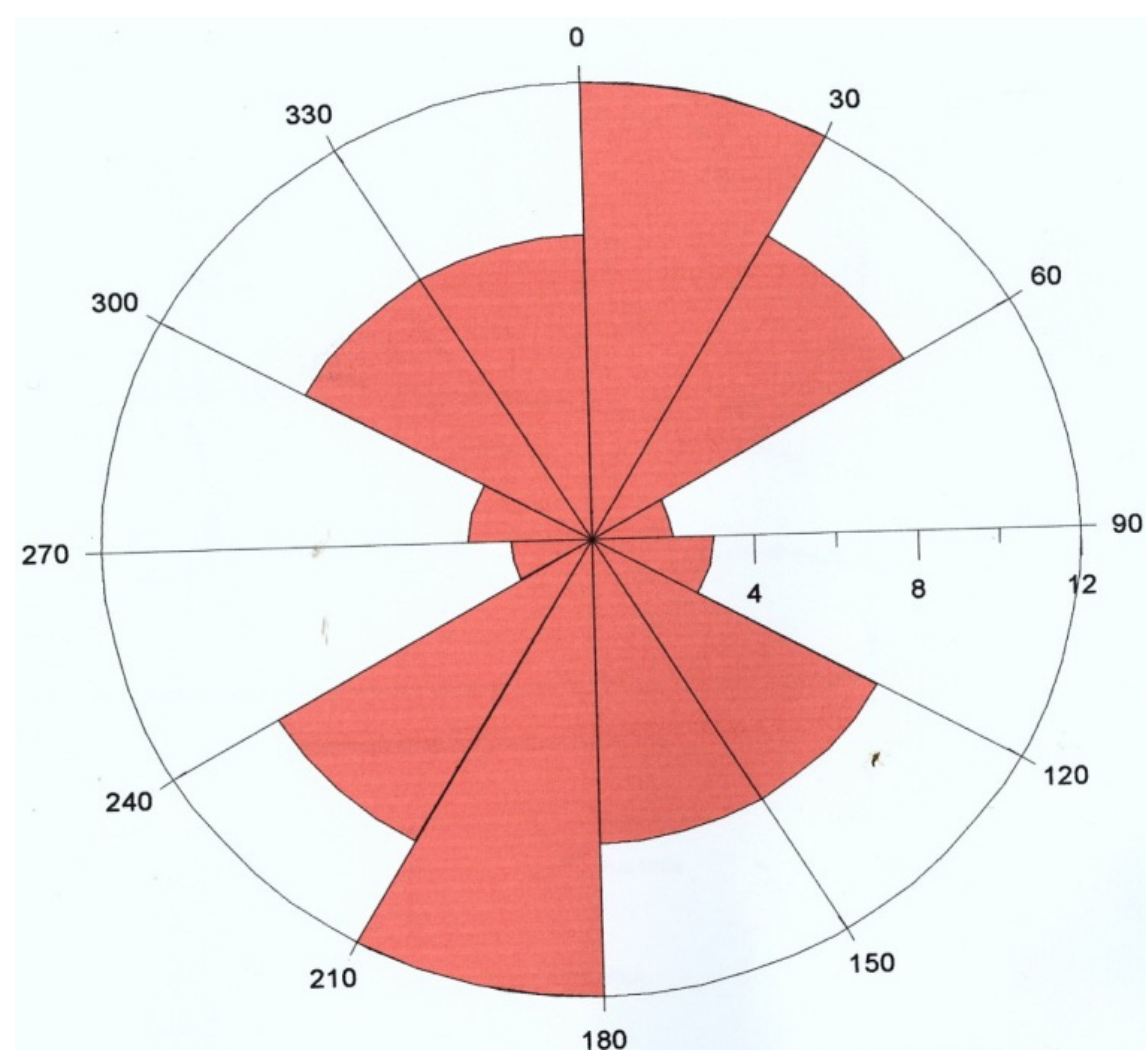

Figure 5. Rosette diagram showing the Principal Joint Direction in the Study Area 


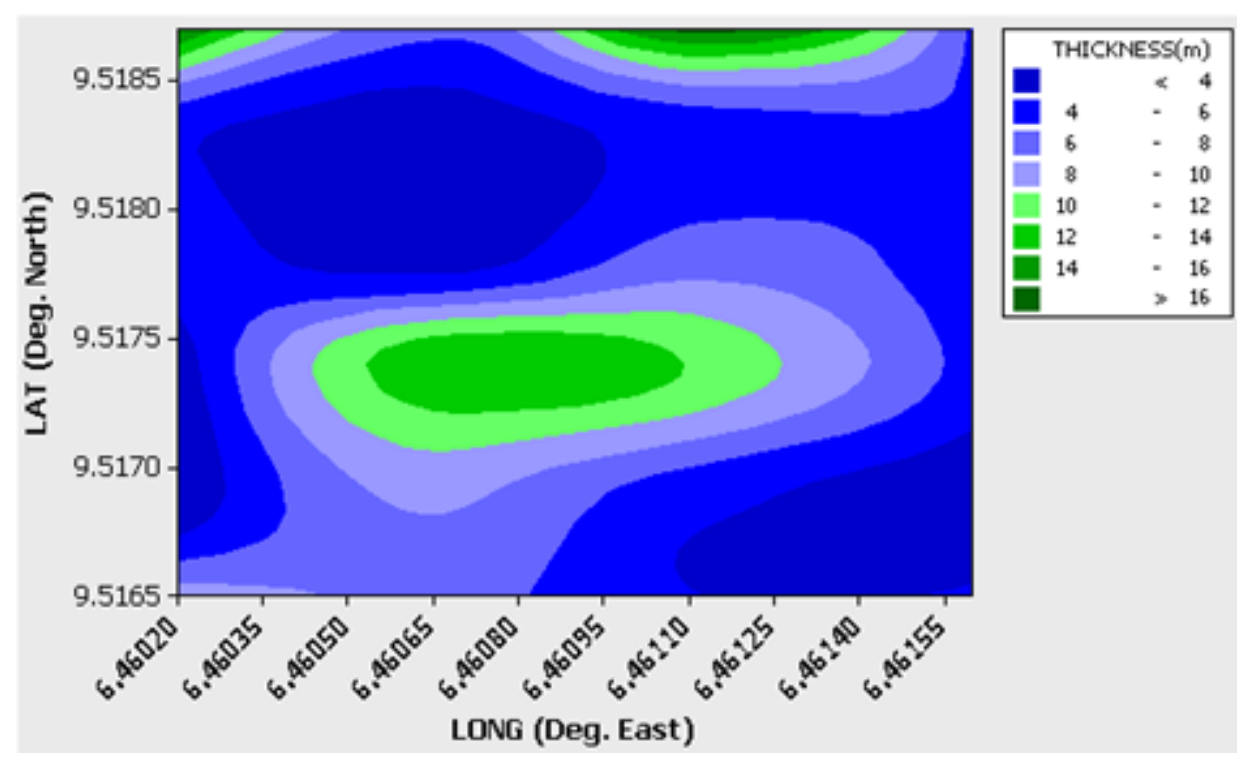

Figure 6. Fracture Map of the Study Area

\section{Conclusions}

An integrated geological and geophysical exploration technique is more suited for efficient and successful groundwater potential studies in Basement Complex Terrain such as Gidan-kwano, Gidan-Mangoro, North-central Nigeria than any geophysical method. The hydrogeological and hydrogeophysical investigation of Gidan-Kwano and Gidan-Mangoro was executed in this study. The H-type curve is the dominant curve type in the area. Three lithologic layers were consisting of highly resistive top soil, low resistivity middle layer of weathered/fractures zone and the highly resistive dry fresh basement rock. This signature was consistent in VES curves, geo-electric section and analyzed borehole strata-log. The effectiveness geological and geophysical techniques in delineating subsurface signatures have been demonstrated in this study and it is recommended that this synergy should be sustained.

\section{REFERENCES}

[1] Amadi, A. N. and Olasehinde, P. I. (2010). Application of remote sensing techniques in hydrogeological mapping of parts of Bosso Area, Minna, North-Central Nigeria. International Journal of Physical Sciences, 5(9), 1465 1474.

[2] Etu-Efeotor, J. O. and Akpokodje, E. G., (1990). Aquifer systems of the Niger Delta. Jour. Min. Geol. 26(2), pp 279-284.

[3] Offodile, M. E., (1983). The occurrence and exploitation of groundwater in Nigeria basement rocks. Jour. Min. and Geol. Vol.1 \& 2, pp 131-146.

[4] Olorunfemi, M. O. and Fasuyi, S. A., (1993). Aquifer types, geoelectric and hydrogeologic characteristics of part of the Central Basement Terrain of Nigeria (Niger State). Journ. African Earth sciences, 16, 309-317.

[5] Olasehinde, P. I. and Amadi, A. N., (2009). Assessment of Groundwater Vulnerability in Owerri and its environs, Southeastern Nigeria. Nigeria Journal of Technological Research, Vol.4, No.1, pp 27-40.

[6] Adeleye, D. R., (1976). The Geology of the Middle Niger Basin: In the Geology of Nigeria, Ed. C. A. Kogbe., Elizabeth Press, Lagos. Pp 283-287.

[7] Ajibade, A. C. and Woakes, M., (1976). Proterozoic crustal development in the Pan-African Regime of Nigeria. In: C. A. Kogbe (Editor) Geology of Nigeria. Published by Rock View (Nigeria) Ltd, pp $57-63$.

[8] Shekwolo, P. D., (1993). Regional Hydrogeology of Bida Basin, Central Nigeria, unpublished Ph.D thesis, Ahmaud Bello University, Zaria.

[9] Grant, N. K., (1978). Structural distinction between a meta-sedimentary cover and underlaying Basement in the $600 \mathrm{MY}$ old Pan Afican domain of North- western Nigeria. Bull., Geol. Soc. Amer. 89, pp 50 - 58.

[10] Olarewaju, V. O., Olorunfemi, M. O. and Alade, O., (1996). Chemical characteristics of groundwater from some parts of the Basement Complex of central Nigeria. Jour. Min. Geol. 33 (2), pp 135-139.

[11] Jimoh, M. O., (1998). Six functional boreholes drilled at Federal University of Technology Minna Permanent Site in Gidan-Kwano. Unpublished technical report submitted to the Works Department, Federal University of Technology Minna, pp 6-14. 